\title{
BIMBINGAN DAN PELATIHAN TENTANG IMPLEMENTASI PRINSIP ETIS DALAM BERBISNIS UNTUK PEMBERDAYAAN PKK RW O3 KELURAHAN KETAWANG GEDE KECAMATAN LOWOKWARU KOTA MALANG
}

\author{
Masreviastuti, Mahmudatul Himma, Fullchis Nurtjahjani, Lilies Nur Aini, Kadek Suarjuna \\ masreviastuti@gmail.com
}

\begin{abstract}
Abstrak - Perkembangan bisnis saat ini telah memasukira globalisasi, dimana terjadi pergerakan komuditas, modal,dan juga manusia yang seolah tanpa batas menembus ke segala penjuru dunia modal paling utama dlam bisnis adalah nama dan kepercayaan. Ukuran etika dan sopan santun dalam dunia bisnis sangatlah keras, kalaulah ada perusahaan yang melangar etika, mereka lebih banyak hukuman dari masyarakat, dibandingkan dari pemerintah karena pada dasarnya juga masyarakat bisnis itu punya jaringan tersendiri, yang sangat luas dan efektif, sehingga setiap pengusaha yang berbuat curang atau tidak etis, maka namanya akan segera tersiar, hal itu tentunya akan merusak nama baiknya sendiri. Etika bisnis itu tidak hanya terlihat dalam hubungan antara pengusaha saja, namun jaga terkait hubungan dengan pemerintah dan tentunya masyarakat. Walaupun sejauh ini ukuran etis atau tidak etisnya praktik perusahan dalam masyarakat masih susah diukur, namun paling tidak kita bisa kembalikan ke hati nurani pengusaha itu sendiri.
\end{abstract}

Kata kunci: etika, bisnis, sopan santun, kepercayaan.

\section{PENDAHULUAN}

\subsection{Latar Belakang}

Terjadinya krisis multi dimensional beberapa tahun terakhir menjadi kan etika bisnis sebagai sorotan dan perhatian dari masyarakat dan para pengamat. Tuntutan masyarakat akan etika dan tolok ukur etika meningkat, hal ini disebabkan pula oleh pengungkapan dan publikasi, kepedulian public, regulasi pemerintah, kesadaran CEO akan etika dan profesionalisme bisnis meningkat.

Jauhnya sentuhan etika atas bisnis disebabkan oleh terlalu terfokusnya perhatian, tanggung jawab dan kewajiban para pelaku bisnis dan manajer untuk memperoleh keuntungan sebesar-besarnya. Usaha untuk meraih keuntungan telah menenggelamkan dan mengubur kesadaran moral para pelaku bisnis untuk berbisnis secara baik dan etis, terlepas dari kenyataan bahwa masih banyak juga pelaku bisnis yang tetap punya kepekaan terhadap kesdaran moral.

Tingkat urgensi perlilaku etis bagi perusahaan sangat menentukan karena dalam jangka panjang bila perusahaan tidak concern dengan perilaku etis dalam bisnis maka kelangsungan hidupnya akan terganggu. Hal ini terjadi akibat manajemen dan karyawan yang cenderung mencari keuntungan sehingga terjadi penyimpangan norma-norma etis, segala kompetensi, ketrampilan, keahlian, potensi, dan modal lainnya diutjukan sepenuhnya untuk memenangkan kompetisi. Dalam jangka pendek mungkin akan meningkatkan keuntungan perusahaan, akan tetapi untuk jangka panjang akan merugikan keuntungan perusahaan, akan tetapi untuk jangka panjang akan merugikan perusahaan itu sendiri akibat hilangnya kepercayaan pelanggan atau konsumen terhadap perusahaan tersebut. (Bertenz,1995) karena kepercayaan merupakan salah satu unsur keutamaan yang sangat vital dalam aktivitas bisnis. Tanpa ada kepercayaan tidak akan ada transaksi dan kemitraan. Penyimpangan atau pelanggaran etika akan mengundang sangsi dari masyarakat bisnis. Bentuknya bisa ditinggalkan konsumen dan relasi, dikomplain langsung, via telepon atau surat pembaca, dan sebagainnya. Akibatnya nama baik akan hancur, sehingga konsumen akan berkurang dan bisnis menjadi terhambat.

Pelanggaran etika bisnis memang banyak dilakukan, namun kita harus selalu mengupayakan untuk menggalakkan etika bisni, paling tidak kita bisa memulai dari pemimpin perusahaan, karena dialah panutan bagi karyawannya. Perilaku etis atau tidak etis dalam perusahaan dikendalikan secara eksplisit maupun implisit oleh budaya perusahaan yang ada. Disini pelatihan etika menjadi aspek penting dari pengedalian perilaku karyawan, karena dalam pelatihan tersebut dapat diberikan pedoman mengenai peraturan dan kebijakan perusahaan, serta perilaku yang dianggap baik atau buruk dalam berbagai situasi.

Di RW 03 Kelurahan Ketawang Gede jumlah anggota PKK yang terdiri dari Ibu-ibucyang jumlahnya 30 orang dengan profesi 90\% : wirausaha, 10\% Karyawan Swasta dan PNS usia antara 30 tahun - 55 tahun dimana mereka selalu melakukan banyak kegiatan bisnis yang berhubungan dengan masyarakat banyak yang perlu dilakukan kerja mandiri dan Tim. Oleh karena itu perlu adanya bekal Ilmu Pengetahuan dan Ketrampilan bagi PKK RW 03 Kelurahan Ketawang Gede Kecamatan Lowokwaru untuk dapat membentuk wirausaha yang sukses dan bermartabat. 


\subsection{Permasalahan Mitra}

Permasalahan yang dihadapi adalah didalam Permasalahan yang dihadapi adalah didalam organisasi baik ketua maupun anggota belum optimal dalam mengelola kegiatan bisnis yang sesuai dengan prinsip etsi dalam berbisnis yang baik dan benar, sebagaimana diketahui bahwasanya Di RW 03 Kelurahan Ketawang Gede jumlah anggota PKK yang terdiri dari Ibu-ibuyang jumlahnya 25 orang dengan profesi $90 \%$ : wirausaha, 10\% Karyawan Swasta dan PNS usia antara 30 tahun - 55 tahun dimana mereka selalu melakukan banyak kegiatan bisnis yang berhubungan dengan masyarakat banyak yang perlu dilakukan kerja mandiri dan Tim. Akibatnya kegiatan bisnis menjadi terhambat dan tidak berkembang dengan baik. Oleh karena itu perlu adanya bekal Ilmu Pengetahuan dan Ketrampilan bagi PKK RW 03 Kelurahan Ketawang Gede Kecamatan Lowokwaru untuk dapat membentuk wirausaha yang sukses dan bermartabat.

\section{TINJAUAN PUSTAKA}

\subsection{Prinsip Dalam Berbisnis}

Secara umum prinsip-prinsip yang dipakai dalam bisnis tidak akan pernah lepas dari kehidupan keseharian kita. Namun prinsip-prinsip yang berlaku dalam bisnis sesungguhnya adalah implementasi dari prinsip etika pada umumnya.( Faisal, Afiff, 2003)

Terdapat beberapa alasan yang menjadikan etika bisnis menjadi sedemikian pentingnya yaitu:

1. Ada kelaziman masyarakat yang sudah maju untuk cenderung menuntut para pebinisnya agar mampu bertindak etis, atau masyarakat pada umumnya mengharapkan kinerja etik yang tinggi.

2. Untuk menghindari kerugian kelompok kepentingan dalam masyarakat, seperti para pelanggan, perantara, pemasok dan pesaing.

3. Untuk melindungi atmosfir berbisnis dari kemungkinan tumbuh suburnya perilaku tidak etis, baik dari karyawan (lingkungan internal) maupun dari para pesaing ( lingkungan eksternal )

4. Untuk melindungi masyarakat yang akan bekerja di sektor bisnis dari ancaman lingkungan kerja yang tidak adil, produk berbahaya, dan bahkan pemalsuan laporan keuangan dan juga memberikan kontribusi pada ketengangan, keamanan dan kenyamanan psikologis bagi para pebisnis.

5. Umumnya orang menginginkan akan bertindak konsisten dengan pandangan hidupnya, menyangkut nilai-nilai kebaikan dan keburukan perilaku dirinya. Sesuatu yang dipaksakan dan bertentangan dengan nilai pribadinya, lazimnya akan melahirkan sumber konflik batin dan strees emosional yang besar.

\subsection{Menjalankan bisnis secara etis dan bertanggung Jawab}

Dalam teori etika, kedudukan nilai (value) sangat krusial dan strategis karena dengan nilailah orang-orang dapat dipersatukan untuk mencapai suatu tujuan yang diharapkan dan dengan nilai pulak onflik dapat terjadi dan diselesaikan. Sebagai bagian dari aksiologi dalam filsafat, etika mengakomodasikan berbagai nilai yang berkembang ditengah-tengah masyarakat. Nilai hanya ada dalam kehidupan manusia.

Manusia dalam organisasi bisnis, memperoleh nilai lebih (value added) merupakan suatu harapan, dengan menganut nilai-nilai terminal dan nilai incremental. Nilai terminal (terminal value) adalah keadaan yang diinginkan seseorang diri bisnisnya baik sebagai nilai yang dimaknai sebagai kepercayaan bersama atau norma kelompok yang telah diserap (internalized) oleh individu (berupa modifikasi), norma yang dimaknai sebagai kepercayaan yang dianut dengan consensus dari suatu kelompok sehubungan dengan kaidah perilaku untuk anggota individual pekerja (karyawan) sebagai mitra kerja, maupun pemilik usaha atau pebisnisnya. Termasuk dalam nilai-nilai terminal ini antara lain adalah sesuatu yang indah, persamaan hak, kebijaksanaan, dan kenyamanan hidupnya.

Sedangkan nilai incremental (incremental value) adalah cara bertingkah laku yang diinginkan untuk mencapai nilai termainal. Dalam hal ini kedudukan nilai incremental lebih merupakan suatu prosesi yang diharapkan dari seseorang dalam mendukung pencapaian tujuan bersama dari bisnis yang diselenggarakan. Contoh dari nilai incremental adalah tingkah laku sopan, bertanggung jawab, pengendalian diri, pengendalian emosi dan sikap ambisi.

\subsection{3. Sumber Sumber Nilai Etika dalam Berbisnis}

Bisnis yang agung dan bermatabat adalah bisnis yang menjunjung tinggi nilai-nilai etika dalam bisnisnya dan pelaku bisnis dengan penuh kesadaran, bukan karena suatu keterpaksaan melaksanakan prinsip-prinsip etika yang berlandaskan moral dalam seluruh rangkaian aktivitas bisnisnya. Untuk mendapatkan pemahaman yang tepat dan memperkaya nilai-nilai moral yang menjadi acuannya diperlakukan referensi dan sumber yang memadai dan tidak menyesatkan. Sumber - sumber yang dapat dan layak digunakan seseorang atau pelaku bisnis bagi kegiatan-kegiatan bisnis yang bernilai etika antara lain adalah filsafat, pengalaman budaya, hukum dan agama.

Sumber utama nilai-nilai etiika yang dapat dijadikan sebagai acuan dan referensi dalam pengolaan dan pengendalian perilaku pebisnis 
dengan aktifitas usaha bisnisnya adalah filsafat. Ajaran-ajaran filsafat tersebut mengandung nilainilai kebenaran yang bersumber dari pemikiranpemikiran filsuf dan ahli filsafat yang terus berkembang sesuai dengan perkembangan

Refrensi penting lainnya yang dapat dimanfaatkan sebagai acuan etika bisnis adalah pengalaman dan perkembangan budaya, baik budaya dari suatu bangsa maupun budaya yang bersumber dari berbagai negara (Cracken, 1986). Budaya yang mengalami transisi akan melahirkan nilai, aturan-aturan dan standar-standar yang diterima oleh suatu komunitas tertentu dan selanjutnya diwujudkan dalam perilaku seseorang, suatu kelompok atau suatu komunitas yang lebih besar

Masyarakat mempengaruhi nilai budaya dari berbagai sumber, tidak ada manusia tanpa nilai. Nilai yang dipengaruhi itu berasal dari berbagai sumber baik budaya, budaya agama, srekolah, maupun pengalaman hidupnya semasa kecil. Budaya yang berkembang ditengah-tengah masyarakat pada suatu periode waktu tertentu akan diteruskan keperiode waktu yang lain, dari satu generasi ke generasi berikutnya. Prosesi pergeseran nilai budaya biasanya dilakukan melalui kelembagaan keluarga, agama dan sekolah.

Untuk menjamin kelanggengan hidup berbangsa dan bernegara pemerintah menyusun dan memberlakukan hukum. Hukum merupakan aturan hidup yang bersifat memaksa dan di pelanggar dapat diberi tindakan hukum yang tegas dan nyata. Hukum moral dalam banyak hal lebih banyak mewarnai nilai-nilai etika. Hukum moral adalah tuntutan perilaku manusia yang ditaati karena kesadaran yang bersumber pada hati nurani dan bertujuan untuk mencapai kebahaigaan.

Agama adalah sumber dari segala moral dalam etika apapun dengan kebenarannya yang absolute. Tiada keraguan dan tidak boleh diragukan nilainilai etika yang bersumber dari agama. Agama berkorelasi kuat dengan moral. Setiap agama mengandung ajaran moral atau etika yang di jadikan pegangan bagi para penganutnya. Pada umumnya, kehidupan beragama yang baik akan menghasilkan kehidupan moral yang baik pula.

\section{SOLUSI DAN TARGET LUARAN}

\subsection{Solusi}

Beberapa solusi yang dapat ditawarkanuntuk mengatasi kendala yang dihadapi adalah sebagai berikut
- Meningkatkan pengetahuan dan kemampuan dibidang kewirausahaan tentang prinsip etis dalam berbisnis serta aplikasi hasil pelatihan ini dalam rangka pengembangan pengetahuan dan ketrampilan serta memperdalam keahliannnya dalam berbisnis

- Menciptakan peluang serta kesempatan untuk berbisnis dan menjalin hubungan dengan relasi dalam rangka meningkatkan ekonomi masyarakat dalam bentuk peningkatan pendapatan, kesejahteraan keluarga dan masyarakat dilingkungan sekitarnya.

- Menjalin hubungan yang lebih erat antara Politeknik Negeri Malang dengan Masyarakat, Lembaga, Instansi, dan Dunia Usaha.

\section{HASIL DAN LUARAN YANG DICAPAI}

\subsection{Pelaksanaan Kegiatan}

Sasaran yang dicapai pada kelompok atau individu peserta pelatihan adalah diharapkan nantinya menjadi bekal dalam menjalankan tugas dan pekerjaannya sebagai anggota PKK RW 03 kelurahan Ketawang Gede Kecamatan Lowokwaru Kota Malang dan sebagai wirausaha sesuai dengan prinsip etis dalam berbisnis diharapkan dapat memberikan kemajuan bagi setiap bisnis yang dimiliki individua tau tim. Dampaknya anggota PKK RW 03 dan masyarakat sekitar akan sejahtera dan dapat menjadi anggota organisasi serta wirausaha yang berkualitas.Setelah mengadakan Pengabdian Kepada Masyarakat, maka untuk melihat keberhasilannya harus dilihat dari hasil dan dampak dari kegiatan tersebut. Saat ini memang harus diakui hasilnya belum nampak, tapi berdasarkan hasil pengamatan selama ini kemajuan sudah mulai ada, ditunjukkan dengan adanya Ibuibu PKK RW 03 kelurahan Ketawang Gede Kecamatan Lowokwaru Kota Malang yang yang mulai memperhatikan dan menerapkan prinsip prinsip etis berbisnis dalam kegiatan bisnis yang mereka miliki. Kegiatan ini dapat dilakukan baik secara formal maupun non formal dengan insentif perjam, per acara, per minggu dan per bulan.

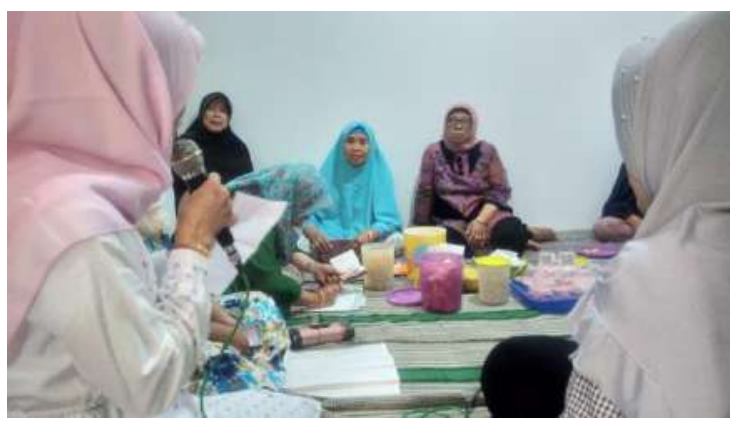

Gambar 1. Sosialisasi Ibu PKK RT 03 


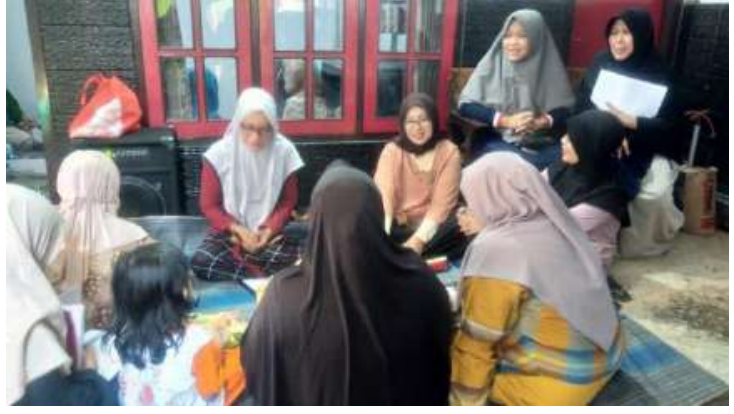

Gambar 2. Penjelasan Materi

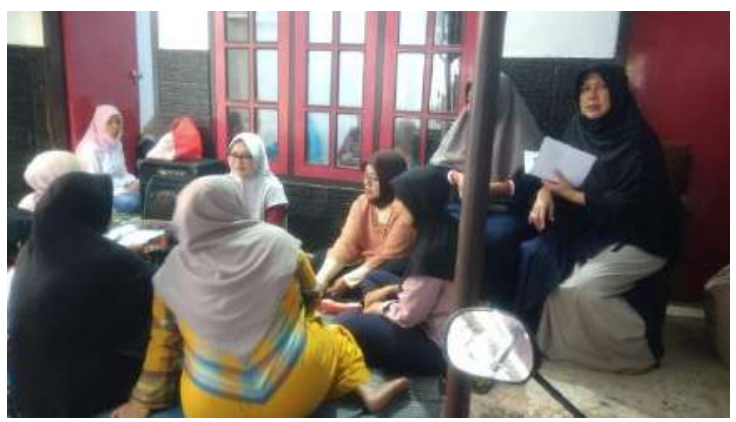

Gambar 3. Tanya Jawab

\subsection{Pembahasan}

Keberhasilan Pengabdian Kepada Masyarakat ini belum dapat dilihat secara langsung, hal ini akan terlihat jika nanti diimplementasikan. Namun jika dilihat dari hasil yang dicapai maka manfaatnya adalah dengan bertambahnya, pengetahuan dan wawasan, ketrampilan yaitu dengan telah mendapat pengetahuan tentang Prinsip Etis Dalam Berbisnis diharapkan dapat membantu mereka dalam mengelola dan menjalankan bisnis mereka.

Pelaksanaan kegiatan Pengabdian Kepada Masyarakat ini dirasa tidak ada faktor penghambat yang serius hanya saja peserta kurang menjalin hubungan yang baik dengan pihak luar atau kurang mempromosikan serta kurang latihan. Dengan ditambah kesabaran dan ketelatenan instruktur, kondisi diatas malah semakin menyenangkan dan bertambah semangat untuk menjalankan yang sesuai dengan Prinsip Etis Dalam Berbisnis.

\subsection{Luaran yang dicapai}

Dengan rata-rata peserta pengabdian masyarakat adalah ibu-ibu dengan usia 30-55 tahun, tingkat pendidikan SMP, SMA, S1, S2, Sarjana dan sederajat dapat dikatakan secara akademis termasuk pendidikan menengah dan pendidikan tinggi sehingga metode pelatihan yang digunakan mudah dimengerti dan mudah dilaksanakan.

Peserta Pengabdian Masyarakat ini mempunyai keinginan yang cukup besar untuk menambah pengetahuan dan ketrampilan di bidang kewirausahaan tentang Prinsip Etis dalam Berbisnis, ditunjukkan dengan jumlah peserta yang hadir 30 orang dan $95 \%$ peserta mengajukan pertanyaan serta $100 \%$ peserta dapat menerapkan prinsip etis bisnis dalam usaha yang sedang mereka jalankan Sebagai hasil evaluasi dari kegiatan pengabdian masyarakat tersebut diatas, inilah salah satu letak keberhasilan Pengabdian Masyarakat yang dilaksanakan.

\section{V.SIMPULAN DAN SARAN}

\subsection{Simpulan}

Setelah dilaksanakannya kegiatan Pengabdian Pada Masyarakat ini maka kegiatan pengabdian dan pengetahuan serta aplikasi yang sangat penting dalam rangka usaha untuk memperoleh tambahan pengetahuan, kemampuan dan penerapan tentang Prinsip Etis dalam Berbisnis. Partisipasi peserta sangat besar hal ini ditunjukkan dengan hadirnya 30 orang peserta dari total jumlah anggota PKK RW 03 kelurahan Ketawang Gede Kecamatan lLowokwaru Kota Malang yang aktif 25 orang yang ikut serta dalam pengabdian ini.

Berdasarkan hasil observasi selama kegiatan pengabdian berlangsung dapat dinilai bahwa $90 \%$ materi dapat diserap

(dimengerti dan dipahami) oleh peserta Pengabdian Masyarakat. Hal ini ditunjukkan dengan sebagian besar peserta yaitu $92 \%$ dari 30 peserta yaitu 27 orang, memberikan pertanyaan tentang Prinsip Etis dalam Berbisnis, peserta juga dapat mempraktekkan dalam usaha yang merekaa kelola.

\subsection{Saran}

Agar supaya ilmu pengetahuan, ketrampilan yang diberikan kepada masyarakat dan peserta pengabdian dapat lebih bermanfaat baik bagi diri sendiri maupun ibu-ibu PKK RW 03 kelurahan Ketawang Gede Kecamatan Lowokwaru Kota Malang maka semua komponen harus bekerja sama untuk mewujudkannya kegiatan bisnis dengan prinsip yang etis di Lingkungan Sekitarnya khususnya dan di kota Malang pada umumnya.

Semua Informasi dan Pengetahuan yang di peroleh hendaknya dapat dipergunakan untuk memecahkan masalah, membuat keputusan yang dapat memberikan kepuasan kepada anggota organisasi.

\section{DAFTAR PUSTAKA}

[1]. Keraf, Sony, 2002, Etika Lingkungan, Jakarta, Penerbit Buku Kompas

[2]. Kotler, Philip, 2003, Marketing Management, Prentice Hall, Pearson, Educational International.

[3]. Pasaribu, R, 2008, Teori Etika Praktis, Medan: Pieter 
[4]. Pudjowiyatna, 2006, Etika Filsafat Tingkah Laku, Bina Aksara, Jakarta

[5]. Puspoprodjo, W, 2010, Filsafat Moral, Bandung: Remaja Karya

[6]. Prately, Peter, 2007, Etika Bisnis, Yogyakarta, Andi Ofset 